\title{
Episodic ataxia type 7
}

INSERM

\section{Source}

INSERM. (1999). Orphanet: an online rare disease and orphan drug data base. Episodic ataxia type 7. ORPHA:209970

Episodic ataxia type 7 (EA7) is an exceedingly rare form of Hereditary episodic ataxia (see this term) characterized by ataxia with weakness, vertigo, and dysarthria without interictal findings. 